OPEN ACCESS

Edited by:

Marcello Chieppa,

National Institute of Gastroenterology

"S. de Bellis", Italy

Reviewed by:

Daniele Corridoni,

University of Oxford, United Kingdom

Aymeric Rivollier,

Technical University of Denmark

Denmark

*Correspondence:

Christoph Mueller

christoph.mueller@pathology.

unibe.ch

$$
\begin{array}{r}
\text { Specialty section: } \\
\text { This article was submitted to } \\
\text { Mucosal Immunity, } \\
\text { a section of the journal } \\
\text { Frontiers in Immunology }
\end{array}
$$

Received: 23 October 2017

Accepted: 04 January 2018

Published: 24 January 2018

Citation:

Brasseit J, Kwong Chung CKC,

Noti M, Zysset D, HoheiselDickgreber N, Genitsch V, Corazza N and Mueller C (2018) Divergent Roles

of Interferon- $\gamma$ and Innate Lymphoid Cells in Innate and Adaptive Immune Cell-Mediated Intestinal Inflammation.

Front. Immunol. 9:23.

doi: 10.3389/fimmu.2018.00023

\section{Divergent Roles of Interferon- $\gamma$ and Innate Lymphoid Cells in Innate and Adaptive Immune Cell-Mediated Intestinal Inflammation}

\author{
Jennifer Brasseit, Cheong K. C. Kwong Chung, Mario Noti, Daniel Zysset, Nina Hoheisel- \\ Dickgreber, Vera Genitsch, Nadia Corazza and Christoph Mueller*
}

Division of Experimental Pathology, Institute of Pathology, University of Bern, Bern, Switzerland

Aberrant interferon gamma (IFN $\gamma$ ) expression is associated with the pathogenesis of numerous autoimmune- and inflammatory disorders, including inflammatory bowel diseases (IBD). However, the requirement of IFN $\gamma$ for the pathogenesis of chronic intestinal inflammation remains controversial. The aim of this study was thus to investigate the role of IFN $\gamma$ in experimental mouse models of innate and adaptive immune cell-mediated intestinal inflammation using genetically and microbiota-stabilized hosts. While we find that IFN $\gamma$ drives acute intestinal inflammation in the anti-CD40 colitis model in an innate lymphoid cell (ILC)-dependent manner, IFN $\gamma$ secreted by both transferred CD4 T cells and/or cells of the lymphopenic Rag ${ }^{-1-}$ recipient mice was dispensable for CD4 T cell-mediated colitis. In the absence of IFN $\gamma$, intestinal inflammation in CD4 T cell recipient mice was associated with enhanced IL17 responses; consequently, targeting IL17 signaling in IFN $\gamma$-deficient mice reduced T cell-mediated colitis. Intriguingly, in contrast to the anti-CD40 model of colitis, depletion of ILC in the Rag ${ }^{-1-}$ recipients of colitogenic CD4 $T$ cells did not prevent induction of colonic inflammation. Together, our findings demonstrate that IFN $\gamma$ represents an essential, or a redundant, pro-inflammatory cytokine for the induction of intestinal inflammation, depending on the experimental mouse model used and on the nature of the critical disease inducing immune cell populations involved.

Keywords: interferon gamma, intestinal inflammation, colitis models, interleukin-17, innate lymphoid cells

\section{INTRODUCTION}

Inflammatory bowel diseases (IBD) comprise two distinct entities, ulcerative colitis (UC) and Crohn's disease (CD), that are characterized by chronic relapsing intestinal inflammation in genetically susceptible individuals (1). Recent genome wide association studies in IBD patients have elucidated distinct genetic defects, which contribute to uncontrolled inflammatory responses and changes in the gut microbiome. The use of animal models has been indispensable in deciphering the complex pathophysiology underlying IBD and in the design of several approved compounds for the treatment of IBD. The therapeutic armamentarium for IBD is constantly growing with anti-TNF agents being at present the treatment of choice, particularly in patients with steroid-resistant IBD. However, around $10-30 \%$ of IBD patients do not respond to TNF targeting strategies or lose responsiveness with progression of disease. Therefore, a better understanding of the complex immune pathways 
underlying IBD pathogenesis is mandatory to develop new effective treatment modalities for patients who are refractory to current treatment protocols.

Among the pro-inflammatory cytokines driving intestinal inflammation, interferon gamma (IFN $\gamma$ ) has been shown to be highly expressed in the affected mucosa of CD patients and to be one of the main drivers of intestinal inflammation in distinct animal colitis models (2). Therefore, it has been proposed that blocking IFN $\gamma$ should have beneficial effects on the development of colitis. In line with this hypothesis, blockade of IFN $\gamma$ during T cell transfer model of colitis in Scid mice was shown to ameliorate intestinal inflammation (3). Similarly, IFN $\gamma$-deficient mice were protected from DSS-induced colitis (4), and in the innate lymphoid cell (ILC) dependent anti-CD40-induced colitis $(5,6)$. While these studies suggested a fundamental role for IFN $\gamma$ in the pathogenesis of intestinal inflammation, other studies have reported that DSS-induced colitis was not significantly affected by neutralizing IFN $\gamma$ (7) and IFN $\gamma$-deficient mice developed 2,4,6-trinitrobenzen sulfonic acid induced colitis to a similar extent as wild-type mice. In humans, therapeutic approaches to target IFN $\gamma$ signaling in IBD patients have shown limited efficacy suggesting that other pro-inflammatory mediators may compensate for reduced IFN $\gamma$ responses to drive intestinal inflammation (8).

The inability to ameliorate colitis by inhibiting IFN $\gamma$ has been attributed to the emergence of pro-inflammatory Th17 cells (9). Whereas Th17 cells are important players in the protection against extracellular and intracellular microbial pathogens such as Candida albicans and Salmonella typhimurium by recruiting neutrophils and activating intestinal epithelial cells (10), elevated IL17A levels have been implicated in intestinal inflammation $(11,12)$. Accordingly, transfer of T cells deficient in ROR $\gamma$ t, i.e., the immune cell-specific isoform of ROR $\gamma$, which is the key transcription factor of Th17 cells in both humans and mice (13), prevented the induction of colitis (14) and numerous studies have shown that IL23, which promotes Th17 cell differentiation, is required for the development of $\operatorname{IBD}(15,16)$. Hence, Th17 cells are considered to be critical effector cells in the development of IBD. Although Th17 cells represent a distinct lineage of CD4 helper T cells, a developmental plasticity of Th17 cell subsets has recently been demonstrated implying that Th17 cells can diverge to acquire Th1-like features through the co-expression of IFN $\gamma$ (17). This transition of Th17 precursors to Th1-like cells was absolutely required for colitis development, as IFN $\gamma$-deficient Th17 cells failed to induce intestinal inflammation (17).

Taken together, while IFN $\gamma$ has been demonstrated to be highly expressed in CD patients as well as in several animal models of colitis, it remains controversial whether IFN $\gamma$ plays an indispensable role in the pathogenesis of IBD. The discrepancy regarding the relevance and source of IFN $\gamma$ for the development of colitis can be attributed to the animal models of colitis used (notably, innate vs. adaptive immune driven colitis, acute vs. chronic models), differences in the hygiene status, and the composition of the intestinal microbiota in the different animal facilities. To specifically address these issues, we aimed to investigate the role of IFN $\gamma$ in two frequently used models of colitis (innate vs. adaptive immune driven colitis models), using genetically and microbiota-stabilized hosts.

\section{RESULTS}

\section{Divergent Roles of IFN $\gamma$ in Innate and Adaptive Immune Cell-Mediated Models of Intestinal Inflammation}

IFN $\gamma$ is a prototypic pro-inflammatory cytokine with pleiotropic functions. Although IFN $\gamma$ has been associated with IBD and experimental models of intestinal inflammation, its role in disease pathogenesis remains controversial. Such controversies may be the result of the mode of disease induction, distinct disease kinetics, genetic background, or variability in the gut commensal community structure in the different vivaria $(18,19)$. Here, we tested the role for IFN $\gamma$ in two well-established models of intestinal inflammation in microbiota-stabilized hosts. Employing a model of innate-mediated intestinal inflammation, we first assessed the role of IFN $\gamma$ in lymphopenic mice in response to anti-CD40 stimulation. While anti-CD40 treated $\mathrm{Rag}^{-/-}$IFN $\gamma$-sufficient mice developed wasting disease and clinical signs of intestinal

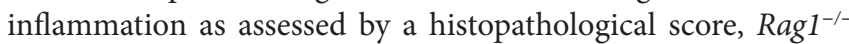
Ifng $^{-/-}$mice were protected from anti-CD40-induced weight loss and acute intestinal inflammation (Figures 1A-C). Consistent with previous report (20), the main source of IFN $\gamma$ in this innate model of acute intestinal inflammation was mostly likely to be derived from group 3 innate lymphoid cells (ILC3) since targeting ILC3 responses by means of antibody depletion (anti-Thy1.2) or employing genetic models that lack ILC3 (Rag2 $^{-/-}$Rorc $^{\text {GFP/ }}$ ${ }_{G F P}$ ) ameliorated colitis (Figures 1A-C). This suggests that ILC3 intrinsic IFN $\gamma$-production was sufficient for induction of acute intestinal inflammation in the anti-CD40 innate colitis model. Given the importance for IFN $\gamma$ and ILC3 in innate immune cellmediated acute intestinal inflammation, we next assessed their role in the CD4 T cell transfer model of colitis. To this end, naive CD4 CD45RB ${ }^{\text {hi }} \mathrm{T}$ cells from IFN $\gamma$-sufficient $\left(\right.$ If $\left.g^{+/+}\right)$or IFN $\gamma$-deficient mice $\left(I f n g^{-/}\right)$were adoptively transferred into lymphopenic IFN $\gamma$ sufficient $\left(\right.$ Rag1 $^{-/-}$Ifng $\left.^{+/+}\right)$or deficient hosts (Rag1 $1^{-/-}$Ifng $\left.^{-/-}\right)$. CD4 T cell expansion in peripheral blood as a sign of colitis onset (19) and body weight were monitored throughout the experiment. Both, IFN $\gamma$-sufficient and -deficient mice developed comparable histopathological changes in the colonic mucosa in response to adaptive CD4 $\mathrm{T}$ cell transfers associated with 10-15\% weight loss of initial body weight (Figures 1D-F). Interestingly, the analysis of the distinct histopathological subscores revealed a statistically significant attenuation of goblet cell loss in the complete absence of IFN $\gamma$ secretion when compared to those experimental groups where either transferred cells and/or recipient cells were capable of secreting IFN $\gamma$ (data not shown). When either colitogenic Ifng ${ }^{-/-} \mathrm{CD} 4 \mathrm{~T}$ cells were transferred into If $\mathrm{Ig}^{+/+} \mathrm{Rag}^{\mathrm{H}^{-/}}$recipients, or upon transfer of colitogenic Ifng ${ }^{+/+} \mathrm{CD} 4 \mathrm{~T}$ cells into Ifng ${ }^{/-}$ Rag $^{-/-}$recipients comparable kinetics of weight loss and extent of histopathological alterations to those shown in Figures 1D-F were seen (data not shown).

While ILC3 promoted the pathogenesis of anti-CD40-induced innate colitis, targeted manipulation of ILC3 in the CD4 T cell 

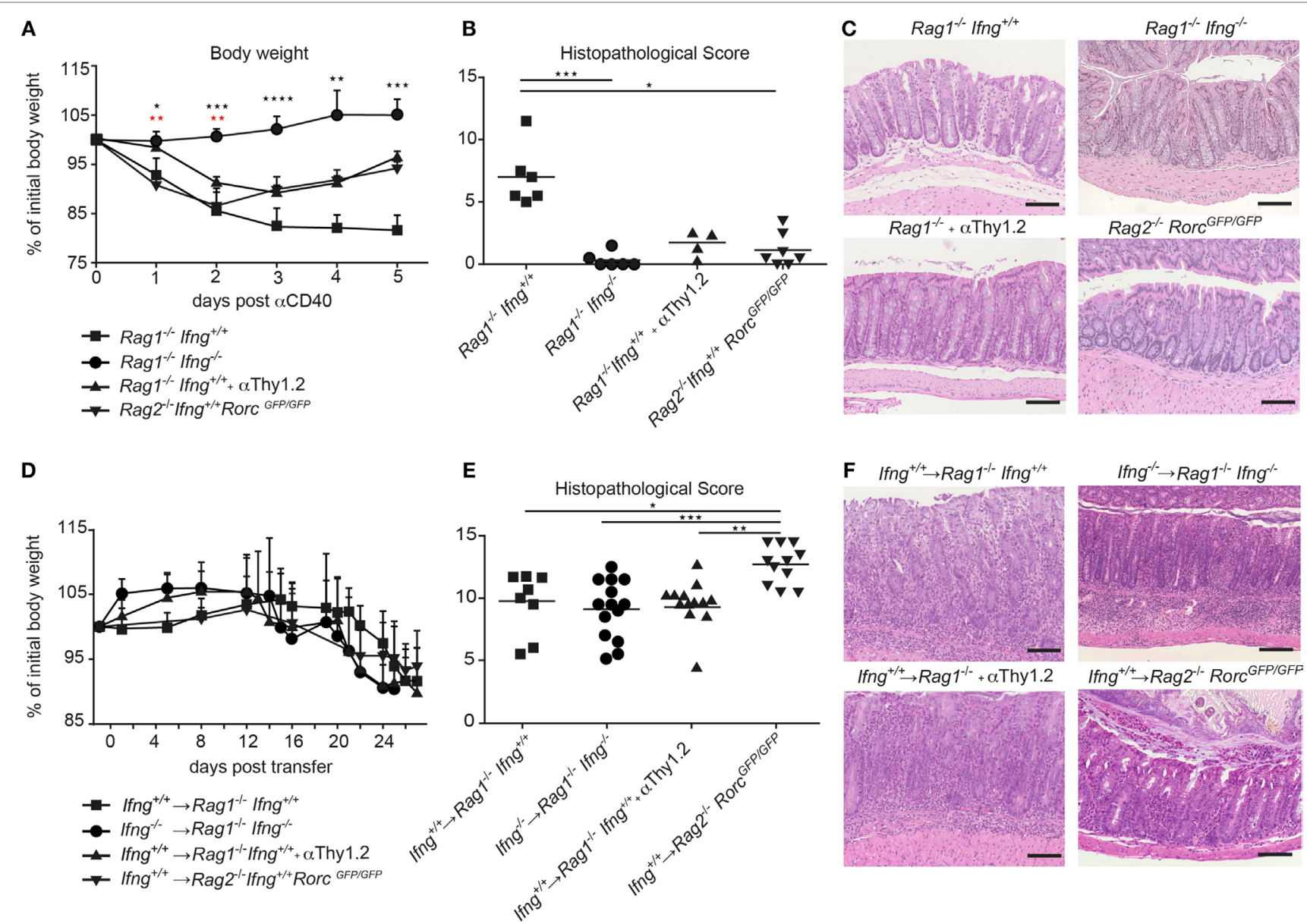

FIGURE 1 | IFN $\gamma$ is critical for induction of innate $\alpha$ CD40, but not for CD4 T cell-mediated colitis. (A-C) Lymphopenic mice were injected with anti-CD40 antibodies or (D-F) transferred with colitogenic T cells to induce colitis. (A,D) Body weight and (B,E) histopathological scores of Rag $1^{1^{-/}}$, Rag $1^{-/-}$Ifng $9^{-/-}$, Rag $1^{-/-}$mice that were $\alpha$ Thy 1.2 treated and Rag2 ${ }^{-/}$Rorc GFP/GFP mice after colitis induction. (C,F) Representative hematoxylin and eosin staining of colonic tissue sections from mice during active phase of colitis. Scale bars indicate $100 \mu \mathrm{m}$. Symbols indicate mean \pm SD (A,D) and individual mice (B,E) of three independent experiments. P-values

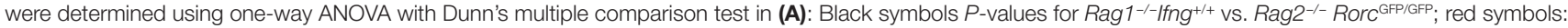

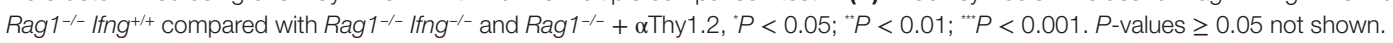

transfer colitis model did not alter disease outcome. Indeed, transfer of colitogenic T cells into congenic $\mathrm{Ragl}^{-/-}$mice depleted of ILC by means of anti-Thy1.2 antibodies or into Rag2 $2^{-/-} \operatorname{Rorc}^{G F P / G F P}$ mice that lack ILC3 resulted in weight loss and intestinal inflammation to similar extent (anti-Thy-1.2 treated), or even more

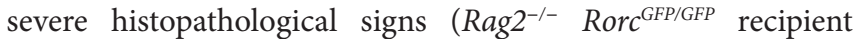
mice) as observed in $\mathrm{T}$ cell-transferred control Rag1 $^{-/-}$mice (Figures 1D-F).

Taken together, we demonstrate that depending on the mode of colitis induction, IFN $\gamma$ is critical for disease induction in the innate anti-CD40 mediated colitis model, whereas IFN $\gamma$ production is dispensable in the CD4 T cell-dependent transfer colitis. Intriguingly, the strict IFN $\gamma$ dependent colitis induction in the anti-CD40 colitis model in Rag1 $1^{-/-}$mice is also associated with a strict dependence on ILC as inducers of colitis while in the presence of colitogenic CD4 T cells ILC and IFN $\gamma$ are not critical for the induction and progression of CD4 $\mathrm{T}$ cell transfer colitis.

\section{Absence of IFN $\gamma$ Favors IL17A Production by Colitogenic CD4 T Cells in the Colon of} Rag 1 $^{-/-}$Recipient Mice

Th1 and Th17 immune cells were previously shown to cooperate in the development of colitis (17). Since CD4 T cell-induced colitis develops in the absence of IFN $\gamma$ (Figures 1D,E), we thus assessed the pro-inflammatory cytokine profile of colitogenic CD4 T cells in the presence or absence of IFN $\gamma$. For this purpose, colitis was induced in $\mathrm{Rag1}^{-/-} \mathrm{Ifng}^{+/+}$or $\mathrm{Rag}^{-/-} \mathrm{Ifng}^{-/-}$mice by adoptive transfer of IFN $\gamma$-sufficient or -deficient CD 4 CD45RB ${ }^{\text {hi }}$ T cells. Upon occurrence of clinical signs of colitis (see Materials and Methods for details), CD4 T cells were isolated from the colonic lamina propria (LP) for subsequent analysis of cytokine responses. Interestingly, in the complete absence of IFN $\gamma$, i.e., when neither host cells nor transferred CD4 T cells are able to produce IFN $\gamma$, we observed increased frequencies and total numbers of IL17A producing colonic CD4 T cells (Figures 2A-D). 

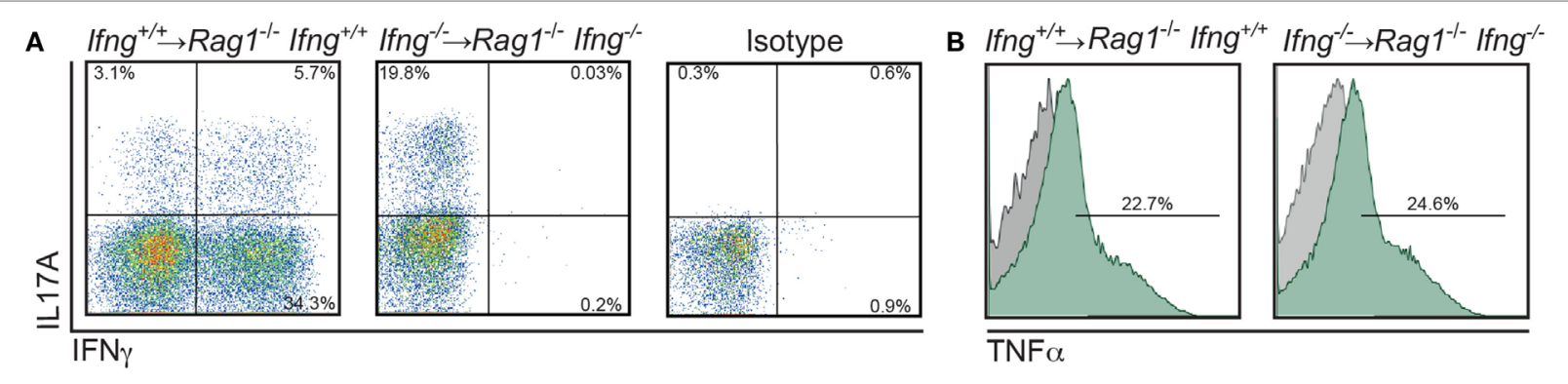

\section{Cell frequency}
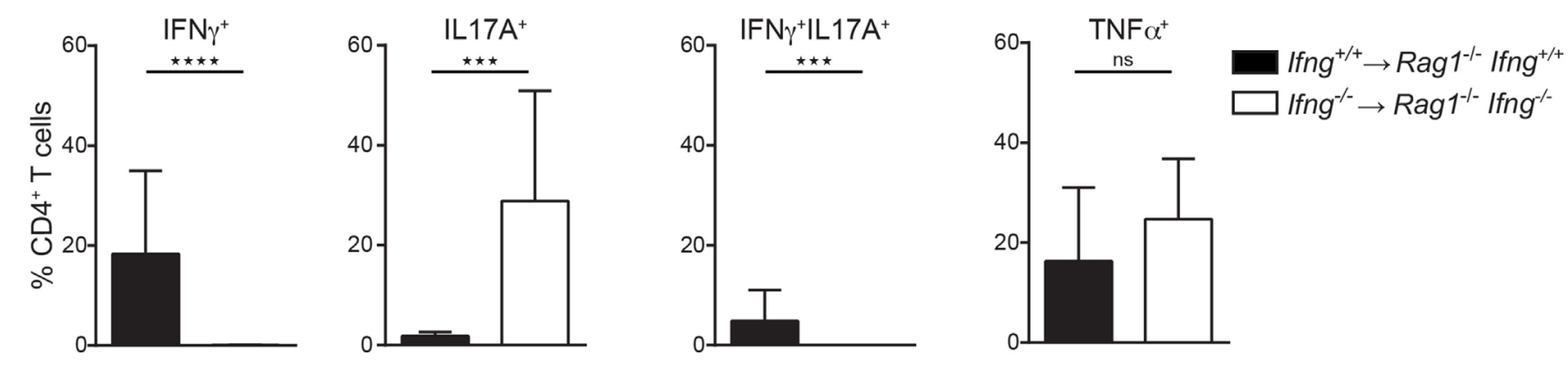

D Cell number
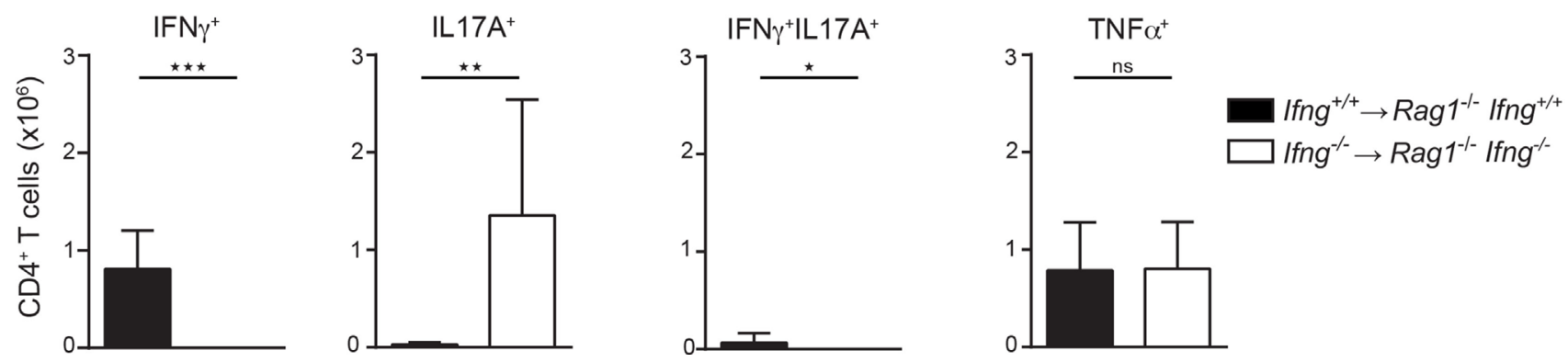

FIGURE 2 | In the absence of IFNy frequencies and numbers of IL17A producing colonic CD4 T cells are dramatically increased in colitic mice. Cytokine expression analysis of colonic lamina propria (LP) CD4 T cells, PMA/ionomycin-stimulated in the presence or absence of IFN $\gamma$. Colonic LP cells were isolated during active

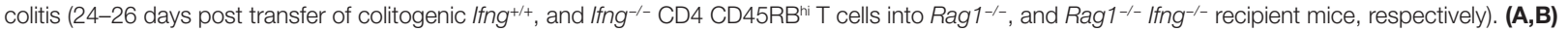
Representative FACS blots showing IFN $\gamma$, IL17A, or TNF $\alpha$ expression of CD4 T cells. (C) Relative cell frequencies and (D) absolute cell numbers of cytokine expressing CD4 T cells. Bars indicate mean \pm SD from three independent experiments with $n=5-9$ mice per group. $P$-value was determined using the two-tailed Mann-Whitney test with 'P $<0.05$; " $P<0.01$; "' $P<0.001$. CD4 T cells were identified as live, single, CD45+ leukocytes, autofluorescent negative, and CD4 CD3 T cells.

In contrast, no changes in $\mathrm{TNF} \alpha$ cytokine production were observed irrespective of whether the host, and/or transferred CD4 T cells were deficient in IFN $\gamma$-expression (Figures 2A-D). Intriguingly, in the presence of host-derived IFN $\gamma$-secreting cells (in If $n \gamma^{+/+} \mathrm{Rag1}^{-/-}$recipients), the differentiation of the transferred If $n \gamma^{-/-}$CD4 T cells into IL17A-producing CD4 T cells is attenuated when compared to If $n \gamma^{-/-} \mathrm{CD} 4 \mathrm{~T}$ cells transferred into Ifn $\gamma^{-/-} \mathrm{Rag}^{-/-}$recipient mice. The differential conversion into IL17A-producing CD4 T cells, however, did not affect the severity, or the kinetics of colitis induction (data not shown).

\section{IFN $\gamma$ Negatively Regulates Th17 Polarization In Vitro}

The observation that in the absence of IFN $\gamma$ signaling colitogenic CD4 $\mathrm{T}$ cells preferentially produce IL17A (Figures 2A-D), prompted us to assess whether IFN $\gamma$ can impede Th17 polarization using an in vitro culture system. To this end, sort-purified CD4 CD45RB ${ }^{\text {hi }} \mathrm{T}$ cells derived from If $n \gamma$-sufficient or -deficient hosts were cultured in vitro under Th17 priming conditions (rmIL6 $(40 \mathrm{ng} / \mathrm{ml}), \operatorname{rhTGF} \beta(6 \mathrm{ng} / \mathrm{ml}), \operatorname{rmIL} 23(20 \mathrm{ng} / \mathrm{ml})$ in 
the presence of neutralizing anti-IL4 $(10 \mu \mathrm{g} / \mathrm{ml})$, and anti-IFN $\gamma$ $(20 \mu \mathrm{g} / \mathrm{ml})$ ) on anti-CD3/anti-CD28 coated plates (1 mg/ $\mathrm{ml}$ ) as previously reported (21) with, or without, recombinant IFN $\gamma$. Importantly, IFN $\gamma$-sufficient and -deficient CD4 T cells produced comparable amounts of IL17A under Th17 priming conditions demonstrating the capacity of naive CD4 T cells to differentiate into Th17 cells irrespective of T cell intrinsic IFN $\gamma$ (Figures 3A,B). Critically, exogenous administration of IFN $\gamma$ to Th17 priming culture conditions significantly reduced the frequencies of IL17A producing CD4 T cells in both IFN $\gamma$-sufficient and -deficient CD4 $\mathrm{T}$ cells (Figures $\mathbf{3 A}, \mathbf{B}$ ). In summary, we demonstrate that IFN $\gamma$ negatively regulates CD4 Th17 cell polarization in vitro irrespective of the intrinsic capacity of CD4 T cells to produce IFN $\gamma$.

\section{Absence of IFN $\gamma$ Shifts the Gene Expression Profile from a Th1-, to a Th17 Cell-Like Signature in Colitic CD4 T Cell- Transferred Rag 1 ${ }^{-/-}$Mice}

To test whether absence of IFN $\gamma$ signaling alters colonic gene expression toward a Th17 cell-like immune profile, we compared mRNA expression levels for Th1 and Th17 related genes in the inflamed colonic mucosa of If $n \gamma$-sufficient, vs. If $n \gamma$-deficient mice. While induction of transfer colitis in Ifn $\gamma$-sufficient mice $\left(\right.$ Ifng ${ }^{+/+} \mathrm{CD} 4 \mathrm{~T}$ cells $\rightarrow$ Rag1 $^{-/-}$Ifng ${ }^{+/+}$mice) resulted in elevated expression of the If $n \gamma$-associated genes Cxcl9 and Cxcl10 in the colon (Figure 4), absence of IFN $\gamma$ (Ifng ${ }^{-/-} \mathrm{CD} 4 \mathrm{~T}$ cells $\rightarrow$ Rag $^{-/-}$ Ifng $^{-/-}$mice) significantly favored the expression of Th17 related genes including Il17a, Il17f, Il22, Ccl20, and Rorgt (Figure 4). Interestingly, while we found a significant shift in the expression of Th1 vs. Th17 associated genes in absence of IFN $\gamma$ signaling, other genes encoding pro-inflammatory mediators including Il6, Gmcsf, Il23p19, and Tnf were expressed at similar magnitudes, showing that IFN $\gamma$ specifically blocks Th17-related gene expression.

Collectively, our findings suggest that IFN $\gamma$ contributes to colonic inflammation but its absence does not prevent $\mathrm{T}$ cell transfer colitis. Given that in the absence of IFN $\gamma$, CD4 T cells acquire a Th17-like phenotype, exaggerated IL17 immune responses may therefore compensate for the lack of IFN $\gamma$.

\section{Targeting Excessive IL17 Responses in IFN $\gamma$-Deficient Hosts Reduces Colonic Inflammation}

Since CD4 T cell-mediated colitis develops in the absence of IFN $\gamma$ production and in the absence of IFN $\gamma$ the CD4 T cells preferentially differentiate into Th17-like cells, we next investigated whether neutralization of excessive IL17 responses in the absence
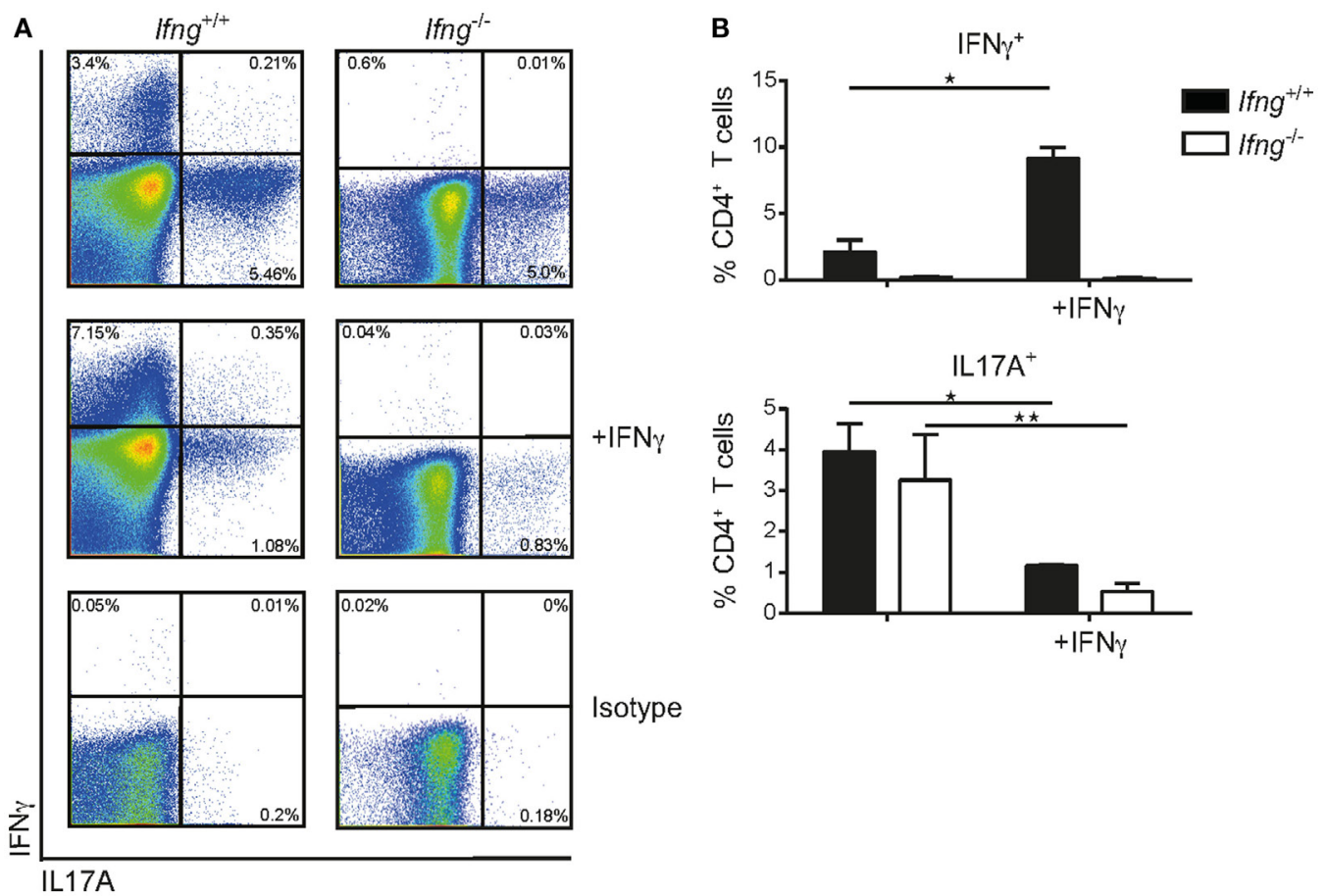

FIGURE 3 | IFN $\gamma$ inhibits differentiation of naïve CD4 CD45RB hi T cells into Th17 cells in vitro. Naïve splenic CD4 CD45RB ${ }^{\text {hi }}$ T cells from Ifng ${ }^{+/+}$or Ifng ${ }^{-/-}$mice were cultured for 8 days under Th17 priming conditions. Cells were restimulated with PMA/ionomycin and stained intracellularly for cytokines. (A) Representative FACS blots of the Th17 primed CD4 T cells from Ifng ${ }^{+/+}$or Ifng $^{-/-}$mice in the presence (adding recombinant mouse IFN $\gamma$ ) or absence of IFN $\gamma$ (anti-IFN $\gamma$ neutralizing antibodies). (B) Relative frequencies of cytokine positive Th17 primed CD4 T cells. Bars indicate mean \pm SD from pooled data from three independent experiments with $n=3-6$ duplicate values per treatment group. $P$-value was determined using one-way ANOVA with Dunn's multiple comparison test with ${ }^{*} P<0.05$; ${ }^{*} P<0.01$. CD4 T cells were identified as live, single, CD45 leukocytes, autofluorescent negative, and CD4 CD3 T cells. 


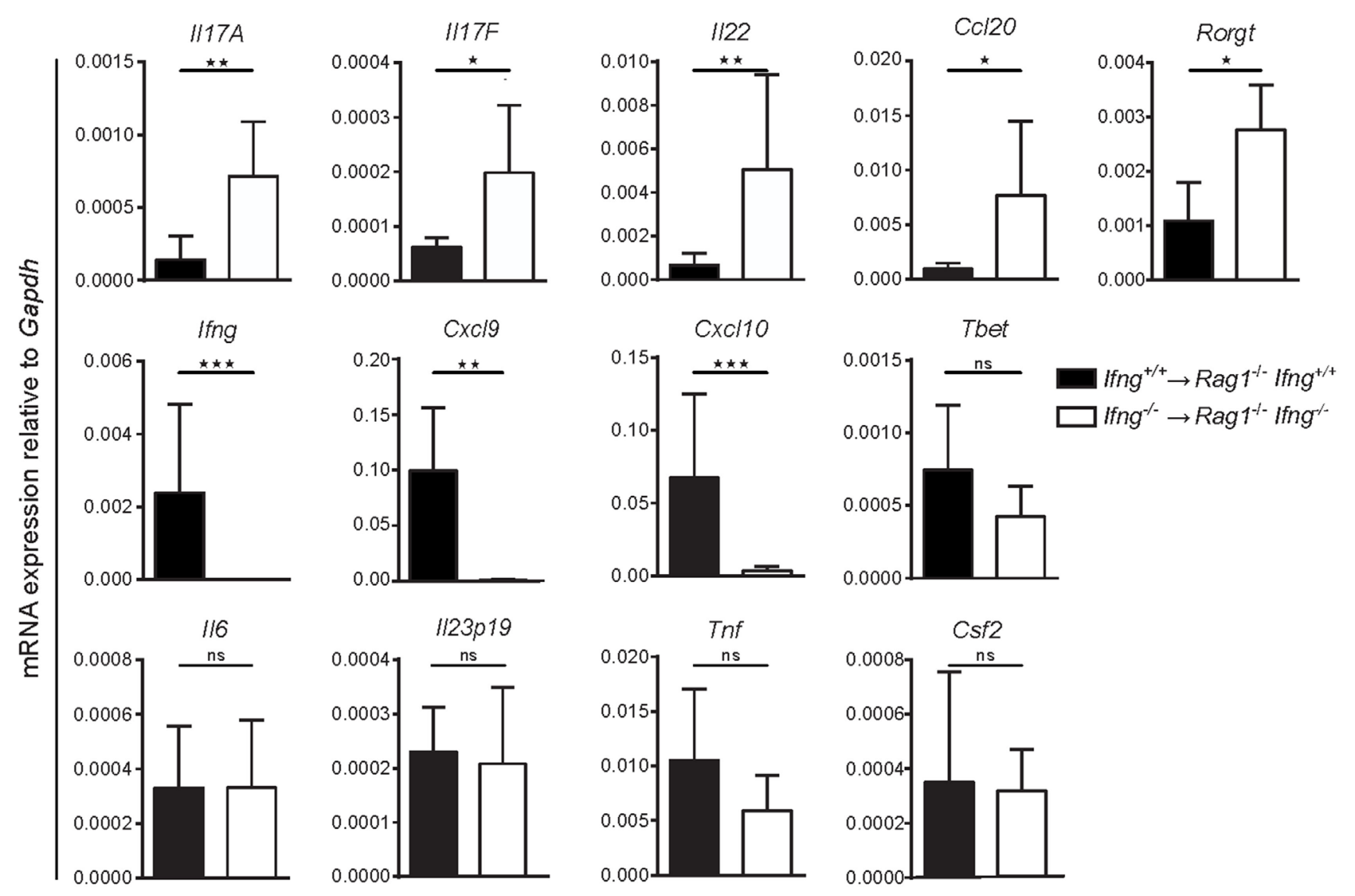

FIGURE 4 | Absence of IFN $\gamma$ shifts the gene expression profile in the affected colon from a Th1-, to a Th17-like signature in CD4 T cell-transferred Rag $1^{-/-}$mice. mRNA expression levels of the indicated genes of whole colonic tissue of Rag $1^{-/-} /$fng $^{+/+}$mice transferred with $/$fng ${ }^{+/+}$colitogenic $T$ cells or Rag $1^{-/-}$Ifng ${ }^{-/-}$mice transferred with Ifng ${ }^{-/}$colitogenic T cells 24-26 days post transfer. Bars indicate mean \pm SD from three independent experiments with $n=5-8$ mice per group. $P$-value was determined using the two-tailed Mann-Whitney test with ${ }^{*} P<0.05$; " $P<0.01$; ${ }^{* * *} P<0.001$.

of IFN $\gamma$ attenuates colonic inflammation. Therefore, Ifng ${ }^{-/-}$CD4 $\mathrm{CD}_{45 \mathrm{RB}}{ }^{\text {hi }} \mathrm{T}$ cells were transferred into Rag1 $^{-/-}$Ifng $^{-/-}$mice for colitis induction and recipient mice were treated with either isotype control antibody or neutralizing antibodies against IL17A and against IL17F twice a week for the duration of the experiment. In the complete absence of IFN $\gamma$ administration of anti-IL17A/F mAb's resulted in a significantly attenuated histopathological score, associated with a significantly reduced weight loss compared to control treated mice (Figures 5A-C). The attenuated weight loss was associated with significantly reduced serum levels of the pro-inflammatory mediators TNF $\alpha$, IL1 $\beta$, and IL6 (Figure 5D). A similar trend for decreased pro-inflammatory mediators in anti-IL17A/F-treated recipients was also detected in the colonic homogenates, although these differences were not statistically significant (data not shown). In contrast, when IL17A and IL17F were neutralized in the presence of IFN $\gamma$-producing cells, the histopathological assessment revealed severe colitis although the total score was slightly lower in anti-IL17A and IL17F treated mice compared to untreated recipient mice (data not shown). Importantly, in response to IL17A/F neutralization, no changes in the frequencies of colonic CD4 T cells nor alterations in their capacity to produce IL17A and TNF $\alpha$ were observed, indicating that the anti-IL17A/F treatment does not lead to a depletion of IL17A/F sufficient CD4 T cells (Figures 5E,F).

Collectively, we demonstrate that targeting exacerbated IL17 secretion in an IFN $\gamma$-deficient environment has disease-limiting properties in the CD4 T cell transfer mouse model of colitis. These findings may be of clinical importance as combinatorial therapies targeting IFN $\gamma$ together with IL17A/F may have disease-limiting effects also in patients with IBD.

\section{DISCUSSION}

The use of experimental models of colitis has critically influenced our understanding of complex immunological processes that mediate the pathogenesis of IBD. In the present study, we strengthen the observations of the differential role of IFN $\gamma$ during innate vs. adaptive murine models of colitis. The importance of IFN $\gamma$ for the development of colitis has been investigated for many years with controversial results. IFN $\gamma$ has been shown to be elevated in the colonic mucosa of IBD patients as well as in several animal model of colitis $(2,22)$ and the beneficial effect of IFN $\gamma$ neutralizing antibodies in T cell dependent animal models of colitis indicated the importance of this cytokine for colitis 


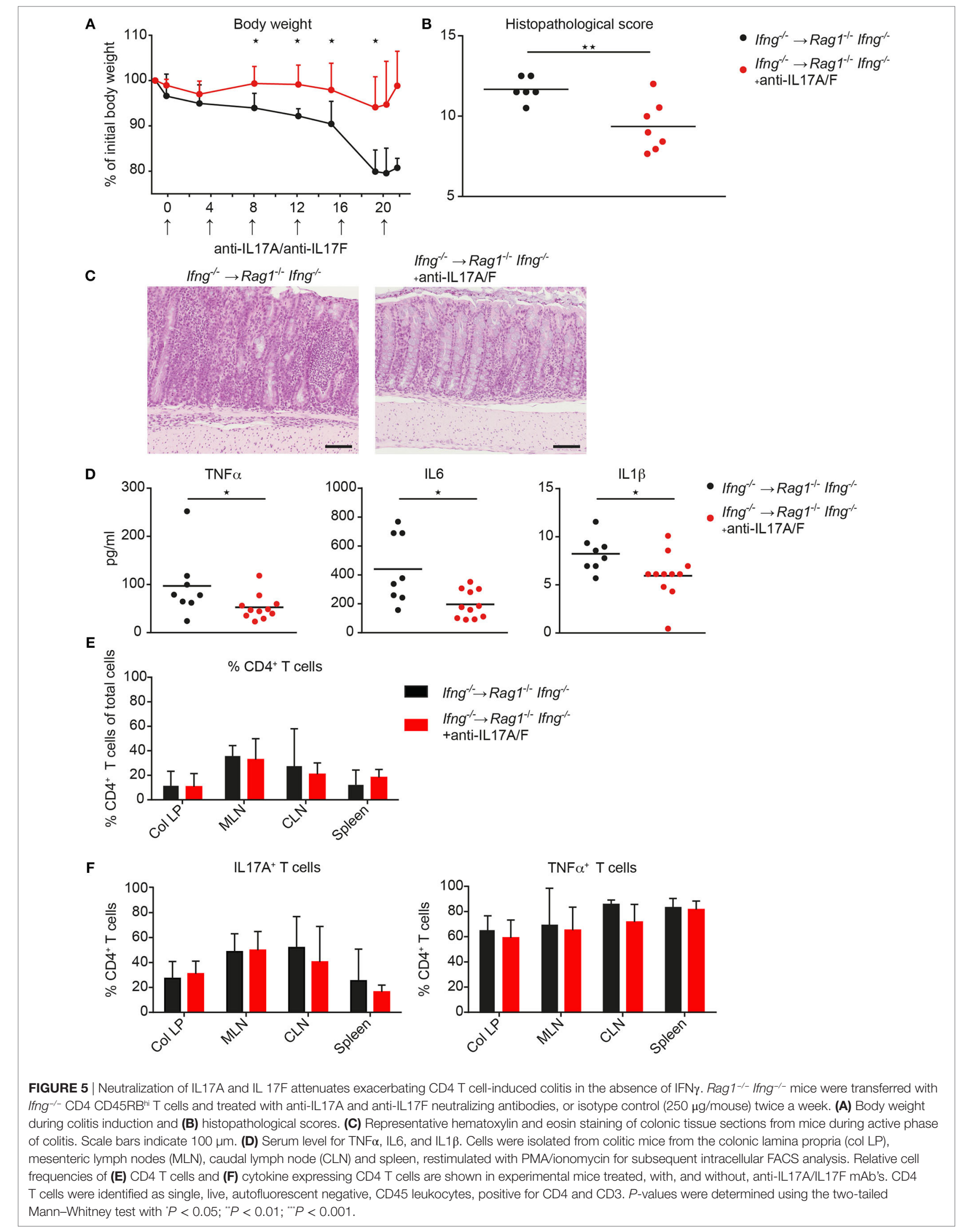


induction (3). These observations were also supported by the fact that T-bet-deficient $\mathrm{T}$ cells failed to induce colitis in adoptive $\mathrm{T}$ cell transfer experiments. This outcome was mainly related to T-bet-dependent induction of Th1 cytokine production, as transferred T-bet-deficient CD4 T cells produced low amounts of IFN $\gamma$ (23). Nonetheless, contradictory results concerning the relevance and source of IFN $\gamma$ in the development of colitis have also been reported. Simpson et al. demonstrated that IFN $\gamma$ expression by $\mathrm{T}$ cells was not necessary for the development of colitis after adoptive transfer (24). Similarly, the use of IFN $\gamma$ neutralizing antibodies in IBD patients seems to be inefficient or only partially beneficial for clinical improvement questioning the role of IFN $\gamma$ in the pathogenesis of IBD (8).

Here, we demonstrated a divergent role of IFN $\gamma$ in the development of colitis. The presence of IFN $\gamma$ is a prerequisite in the anti-CD40 model of colitis whereas by using the T cell transfer model of colitis we clearly demonstrate that IFN $\gamma$ is not necessary for the development of colitis as mice developed disease in the complete absence of IFN $\gamma$. Colitis induction in the absence of IFN $\gamma$-producing $\mathrm{T}$ cells is preferentially driven by Th17-related mediators including IL17A and IL17F. Inhibition of IL17A and IL17F in the absence of IFN $\gamma$ partially protected mice from developing intestinal disease. In contrast, when IL17A and IL17F were neutralized in the presence of IFN $\gamma$-producing cells minimal effect on weight loss or histopathological scores was observed indicating that inhibition of Th17 cytokine per se is not sufficient for the protection of colitis induction (data not shown).

The contribution of IL17A/F to the pathogenesis of chronic intestinal inflammatory disorders has been investigated in several animal models with conflicting results. On one hand, disease promoting effects in mouse models of colitis were ascribed to IL17A/F-mediated signaling as blocking IL17A and IL17F ameliorated disease $(14,25)$. In support of our findings, IL17-driven responses were exacerbated in the absence of the transcription factor T-bet, which commits CD4 T cells to the Th1 lineage (26). On the other hand, protective effects of IL17A were ascribed to an IL17A-mediated attenuation of T-bet and IFN $\gamma$ expression, leading to a more aggressive colitis upon transfer of IL17A ${ }^{-/-}$CD4 T cells into lymphopenic hosts (27). Furthermore, anti-IL17A treatment failed to attenuate colitis induced by adoptive transfer of $\mathrm{Tb} \times 21^{-/-} \mathrm{CD} 4 \mathrm{~T}$ cells in $\mathrm{Rag} 1^{-/-}$recipients (28). IL17A also enhances intestinal barrier functions by counteracting IFN $\gamma$ triggered intestinal epithelial permeability $(29,30)$.

The findings of a disease-attenuating effect of IL17A in some, but not all, mouse models of colitis is also reflected in human studies that showed exacerbation of intestinal inflammation in IBD patients treated with IL17 targeting biologicals $(31,32)$. Although in the present study, we primarily aimed to assess the precise impact of IFN $\gamma$ rather than IL17 on the development of colitis in two separate mouse models, our results support the idea that IL17 compensates for the absence of T cell-derived IFN $\gamma$ to drive colitis induction, suggesting that both the IFN $\gamma$ - and IL17-mediated effects are targeted to attenuate chronic intestinal inflammation. In support of this, it has been reported that IL17A blockade by Secukinumab (AIN457) is ineffective in CD patients with higher rates of adverse events observed in these patients compared with placebo group (31). In addition, phase II trials with Ustekinumab which blocks the p40 subunit of IL12 (which is required for Th1 cell development) and IL23 (which is required for the maintenance of Th17 cells) has shown beneficial effects in CD patients (33). Of note, the use of the dihydroorotate dehydrogenase inhibitor Vidofludimus (SC12267) which attenuates IL17A/F and IFN $\gamma$, is also in clinical trials and it remains to be seen whether it has the potential of becoming useful treatment modalities in IBD patients (34).

The observation that both IFN $\gamma$ and IL17 responses alone can induce colitis (in a $\mathrm{T}$ cell dependent model) raised the question of whether there is a "division of labor" between Th1 and Th17 responses in promoting intestinal inflammation or whether Th1 can regulate Th17 responses and vice versa. Our findings show that IFN $\gamma$ antagonizes IL17 responses, and absence of IFN $\gamma$ results in a predominant IL17-driven immune response that is sufficient to induce colitis. This is in agreement with previous report showing that absence of T-bet results in an exacerbated Th17 response due to the increased responsiveness of T-bet ${ }^{-/-} \mathrm{CD} 4 \mathrm{~T}$ cells to IL-23 (26). The IFN $\gamma$-mediated downregulation of IL17 immune response may occur through the inhibition of Stat3 and Roryt transcription factor (21). This suppression has also been further emphasized in other disease models where IFN $\gamma$ blockade even led to an exacerbation of disease by increasing Th17 immune responses, e.g., in experimental autoimmune encephalomyelitis, collagen-induced arthritis, or experimental autoimmune uveitis (35-37).

Recent reports demonstrated that Th17 cells retain late developmental plasticity and have the ability to divert into Th1like features (17). Consequently in addition to the production of IL17A and IL17F, Th17 also can produce IFN $\gamma$. Importantly, while in vitro differentiated IFN $\gamma$ expressing Th17 cells can induce colitis after adoptive transfer, in vitro IFN $\gamma$-deficient Th17 cells (still expressing IL17) are unable to induce disease in recipients (17). In this model, development of disease required the transition of a subset of Th17 precursors into Th1-like cells. Moreover in the same report, they demonstrated that Th17 cells, which are unable to produce IFN $\gamma$, supported the de novo differentiation of Roryt deficient naïve CD4 CD45RB ${ }^{\text {hi }} \mathrm{T}$ cells into pathogenic IFN $\gamma$ producing Th1 cells. Single transfer of either Roryt deficient naïve CD4 CD45RB ${ }^{\text {hi }}$ or IFN $\gamma$-deficient Th17 $\mathrm{T}$ cells did not induce disease, pointing to a principal role of IFN $\gamma$ for colitis development. Our results are in contrast with this model since in our hands CD4 T cell transfer colitis is induced even in the absence of IFN $\gamma$. Taken together, this suggests that while IFN $\gamma$ expression by Th17 T cells is a prerequisite for colitis induction when the cells were functionally polarized in vitro before colitis induction, in vivo priming of naïve T cell into Th17 $\mathrm{T}$ cells is sufficient for colitis induction and does not require the presence of IFN $\gamma$. This is in line with a report by Shen et al. who demonstrated that optimal CD4 T cell priming in the selective environment in vitro will lead to a strong polarization of CD4 $\mathrm{T}$ cells with limited functional plasticity, whereas in vivo, naïve CD4 T cells will retain their functional plasticity and diversity upon transfer in lymphopenic recipients (38). The differential mode of CD4 $\mathrm{T}$ cell priming may thus explain some of the observed discrepancies with regard to the role of IFN $\gamma$ and/or IL17 in colitis induction. 
Recent progress in the understanding of the pathogenesis of chronic intestinal inflammation in mouse models and patients with IBD revealed important contribution from myeloid and lymphoid innate immune cells to the onset of intestinal inflammation. In particular, ILC have emerged as key players in mucosal immunity by producing large amounts of pro-inflammatory cytokines such as IL17, IL22, and IFN $\gamma$. Their role in driving intestinal inflammation has been described in several colitis models $(5,39)$. Nevertheless, using the transfer model of colitis we demonstrated that ILC depleted recipient and Rag2 $2^{-/-} \operatorname{Rorc}^{\text {GFP/GFP }}$ mice were not protected from colitis. These results indicate that in an animal model where antigen activated $\mathrm{T}$ cells are required for colitis induction the presence of ILC is irrelevant for the outcome of colitis. In line with this idea, using a $\mathrm{T}$ cell independent model of colitis, we showed that mice were fully protected from colitis in the absence of IFN $\gamma\left(\right.$ Ragl $^{-/-}$Ifn $\gamma^{-/-}$mice $)$or in the absence of ILC

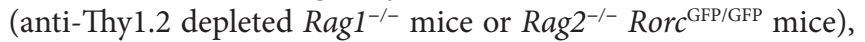
in agreement with previous studies $(20,39)$. These results indicate that while IFN $\gamma$ is redundant in a T cell model of colitis, IFN $\gamma$ is absolutely required for $\mathrm{T}$ cell independent disease development in the anti-CD40 mouse model of colitis where also the absence of IFN $\gamma$ cannot be compensated by IL17.

Furthermore, these data also corroborate the concept that mouse $\mathrm{T}$ cells and ILC show overlapping functions in infection and inflammation (40) where in the presence of adaptive $\mathrm{T}$ cells the critical contributions of ILC seen in adaptive immune cell-deficient mice may not be further evident. This has been recently demonstrated also for the relevance of IL22-producing ILC3 in the protection against colonic infection with Citrobacter rodentium. In this model, the requirement for NKp46 ILC3 for protective immunity seen in C. rodentium infected $\mathrm{Rag}^{-/-}$mice was not observed in $C$. rodentium infected immunocompetent mice, which were able to control $C$. rodentium infection in the colon even upon selective depletion of NKp46 $6^{+}$ILC3 (41).

In conclusion, we clearly reveal a distinct role of IFN $\gamma$ for the development of intestinal inflammation in two different mouse models of colitis in the same mouse strain with the same microbial composition. In the absence of an adaptive T cell response, ILCderived IFN $\gamma$ is essential for mediating intestinal inflammation. On the other hand, IFN $\gamma$ is not required for intestinal inflammation in the CD4 T cell transfer model, where in the absence of IFN $\gamma$ production, the colitogenic CD4 T cells preferentially differentiate into IL17 secreting cells. These data thus suggest that for an effective treatment of patients with IBD, not only IFN $\gamma$, but also IL17A/F activity needs to be targeted.

\section{MATERIALS AND METHODS}

\section{Mice}

C57BL/6 mice were purchased from Harlan (Horst, The Netherlands), Thy1.1 C57BL/6, Rag1-/- and Ifng $^{-/-}$mice were obtained from the SwIMMr (University of Zurich, Switzerland). $\mathrm{Rag1}^{-/-}$mice were crossed to Ifng ${ }^{-/-}$mice to obtain $\mathrm{Rag1}^{-/-}$Ifng $^{-/-}$

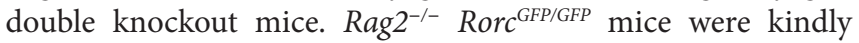
provided by B. Becher (University of Zurich, Switzerland). Mice were maintained under specific pathogen-free conditions at the central animal facility of the Medical School of the University of Bern or at the Institute of Laboratory Animal Science, University of Zurich.

\section{Antibodies and Flow Cytometry}

Anti-mouse CD45RB (16A) antibody was purchased from BD Pharmingen (San Diego, CA, USA). CD25 (PC61) antibody was purchased from eBioscience (San Diego, CA, USA). Anti-mouse CD4 (RM4-5), CD3 (145-2C11), TCR $\alpha \beta$ (H57-597), CD45 (30-F11), IFN $\gamma$ (XMG1.2), IL17A (clone TC11-18H10), TNF $\alpha$ (MP6-XT22), Thy1.2 (53-2.1), and Thy1.1 (OX-7) were purchased from Biolegend. For intracellular staining dead cells were excluded using the LIVE/DEAD ${ }^{\circledR}$ fixable dead cell stain kit (blue) from Invitrogen. After washing and surface staining, intracellular cytokine staining was performed using the FoxP3 staining kit from eBioscience. Biotinylated anti-mouse CD8 $\alpha$ (53-6.7) and B220 antibodies were purified from hybridoma supernatants. Cells were acquired on a LSRII SORP (BD Biosciences, San Diego, CA, USA) and analyzed using FlowJo software (Tree Star, Ashland, OR, USA).

\section{Colitis Models}

\section{Anti-CD40-Mediated Colitis}

Mice were injected i.p. with the anti-CD40 monoclonal antibody (clone FGK45, BioXcell; 150 $\mu \mathrm{g} / \mathrm{mouse}$ ). After antibody injection, mice were observed daily and sacrificed after 5 days for subsequent immunological and histopathological analyses.

\section{T Cell Transfer Colitis}

$\mathrm{T}$ cell transfer colitis was performed as described previously with minor modifications (42). Splenocytes from C57BL/6, Thy1.1 C57BL/6 or Ifng-/- mice were enriched for CD4 T cells by MACS-depletion of CD8 and B220 cells (Miltenyi Biotec, Bergisch Gladbach, Germany). Enriched CD4 T cells were then sorted on a FACS Aria Cell Sorter (Becton Dickinson, San Jose, CA, USA) to obtain CD4 CD25-CD45RB ${ }^{\text {hi }}$ T cells. Rag1 ${ }^{-/-}$, $\mathrm{Rag1}^{-/-}$Ifng $^{-/-}$, and Rag2 ${ }^{-/-}$Rorc $^{\text {GFP/GFP }}$ mice were injected i.p. with $2 \times 10^{5}$ sort-purified CD 4 CD25 ${ }^{-}$D $45 \mathrm{RB}^{\text {hi }} \mathrm{T}$ cells. For depletion of ILC, Thy $1.2^{+}$recipients of Thy1.1 $1^{+}$CD4 T cells were injected with anti-Thy1.2 depleting antibodies i.p. [clone 30H12, $500 \mu \mathrm{g} /$ mouse (BioXcell, West Lebanon, NH, USA)]. For targeting IL17 responses in vivo, mice were injected twice a week i.p. with neutralizing antibodies against IL17A and IL17F for the duration of the experiment (anti-IL17A clone 17F3, $250 \mu \mathrm{g} /$ mouse (BioXcell, West Lebanon, USA), anti-IL17F (L31409-098), $250 \mu \mathrm{g} /$ mouse kindly provided by Pfizer). All animals were monitored regularly for weight loss and normal activity and sacrificed at the onset of clinical signs of colitis (defined by weight loss $\geq 15 \%$ and/or diarrhea for $\geq 24$ time; altered behavior for $\geq 48$ time; or bloody stool) at 24-28 days post disease induction.

\section{Histopathological Assessment}

Intestinal tissue specimens from the colon were fixed in $4 \%$ paraformaldehyde for subsequent paraffin embedding. 
Deparaffinized tissue sections were stained with hematoxylin and eosin for histological scoring based on the following parameters: (1) infiltration of the LP of the large bowel (score from 0 to 3), (2) mucin depletion/loss of goblet cells (score from 0 to 3), (3) crypt abscesses (score from 0 to 3), (4) epithelial erosion (score from 0 to 1), (5) hyperemia (score from 0 to 2), and (6) thickness of the colonic mucosa (score from 0 to 3 ). Hence, the histopathological score ranges from 0 (no alteration) to 15 (most severe signs of colitis). Histological scoring was performed by a pathologist (VG) blinded to sample identity.

\section{Cell Isolation}

Colonic LP cells were isolated as described previously with minor modifications (43). Briefly, tissues were placed in $\mathrm{Ca}^{2+}$ and $\mathrm{Mg}^{2+}$-free Hanks' balanced salt solution (HBSS) containing $10 \mathrm{mM}$ Hepes, $2 \%$ horse serum (HS), $0.5 \mathrm{mM}$ EDTA, and $2 \mathrm{mM}$ DTT at $37^{\circ} \mathrm{C}$ for $30 \mathrm{~min}$ to detach epithelial cells, followed by $30^{\prime}-45^{\prime}$ incubation HBSS/HEPES buffer containing $5 \%$ HS and $100 \mathrm{U} / \mathrm{ml}$ collagenase type IV (Sigma, St. Louis, MO, USA) and $50 \mathrm{U} / \mathrm{ml}$ DNase (type I, grade II; Roche) at $37^{\circ} \mathrm{C}$. Isolated cells from the LP were then passed through a $70 \mu \mathrm{m}$ cell strainer for subsequent counting and FACS analysis. Cells from mesenteric and caudal lymph nodes and spleen were isolated by squeezing the organs through a $40 \mu \mathrm{m}$ cell strainer. Blood samples were collected from the tail vein (or the heart on days of analysis) into PBS containing $10 \mathrm{mM}$ EDTA and 5\% HS. Erythrocytes in blood samples and spleens were lysed using ACK lysis buffer. Cells were subsequently counted and stained for flow cytometric analyses. Absolute cell numbers were calculated based on the relative frequency of particular cell subsets and total number of viable cells in the respective lymphoid compartment. Results were plotted using GraphPad Prism (GraphPad Software, La Jolla, CA, USA).

\section{Cell Culture and Re-Stimulations}

Cells isolated from the LP, spleen, and mesenteric lymph nodes were cultured in 96 -well $\mathrm{U}$-bottom plates at $37^{\circ} \mathrm{C}, 5 \% \mathrm{CO}_{2}$ in Iscove's modified Dulbecco's Medium (IMDM) containing 10\% fetal calf serum (FCS) and $5 \mathrm{mM}$ glutamine. Cells were stimulated with PMA (20 ng/ml, Sigma, St. Louis, MO, USA) and ionomycin $(2 \mu \mathrm{g} / \mathrm{ml}$, Sigma, St. Louis, MO, USA) for $5 \mathrm{~h}$. After $2 \mathrm{~h}$ of culture, brefeldin A $(10 \mu \mathrm{g} / \mathrm{ml}$, Sigma, St. Louis, MO, USA) was added to the culture. After $5 \mathrm{~h}$, cells were harvested and FACS stained. To exclude dead cells, the LIVE/DEAD ${ }^{\circledR}$ fixable dye was applied (Invitrogen, Carlsbad, CA, USA) according to the manufacturer's manual. Subsequently, cells were surface stained followed by intracellular cytokine staining using the FoxP3 staining kit from (eBioscience, San Diego, CA, USA).

For in vitro priming of naïve CD4 T cells, sort-purified CD4 CD45RB ${ }^{\text {hi }} \mathrm{T}$ cells were cultured in IMDM medium (10\% FCS, $5 \mathrm{mM}$ glutamine) for 8 days under Th17 priming conditions: rmIL6 $(40 \mathrm{ng} / \mathrm{ml}), \operatorname{rhTGF} \beta(6 \mathrm{ng} / \mathrm{ml}), \operatorname{rmIL} 23(20 \mathrm{ng} / \mathrm{ml})$ on anti-CD3/anti-CD28 coated plates $(1 \mathrm{mg} / \mathrm{ml})$ in the presence of neutralizing antibodies [anti-IL4 $(10 \mu \mathrm{g} / \mathrm{ml})$, anti-IFN $\gamma(20 \mu \mathrm{g} /$ $\mathrm{ml})$, or IFN $\gamma(10 \mathrm{ng} / \mathrm{ml})]$. All cytokines were purchased from Peprotech (Hamburg, Germany).

\section{RNA Isolation, cDNA Synthesis, and qRT-PCR}

Whole tissues were preserved in RNA-later (Ambion, MA, USA) and sort-purified CD4 T cells in TRI-reagent and stored at $-80^{\circ} \mathrm{C}$ until RNA isolation. RNA was isolated using TRI-reagent according to the manufacturer's instructions (Molecular Research Centre, Cincinnati, OH, USA). Genomic DNA was digested with DNase I (Sigma), and cDNA was generated with the Superscript II kit (Applied Biosystems, Muttenz, Switzerland). Samples were run on an Applied Biosystems 7500 Real-time PCR system with Quantitect Primer Assays (Qiagen, Düsseldorf, Germany). Results were normalized using the $\Delta \Delta$ cycle threshold method relative to the housekeeping gene Gapdh.

\section{Statistical Analysis}

All data were analyzed and plotted using Graphpad Prism 6 and results are depicted as mean \pm SD. Statistical analysis was performed as described in the figure legends. In general, the twotailed Mann-Whitney $t$-test was used to compare two groups. One-way ANOVA with Tukey's multiple or Dunn's multiple comparison test was used when three or more groups were compared with each other. Results were considered significant with ${ }^{*} P<0.05 ;{ }^{* *} P<0.01 ;{ }^{* *} P<0.005 ;{ }^{* * *} P<0.001$.

\section{ETHICS STATEMENT}

All animal experiments were performed in compliance with Swiss laws and with the approval by the animal experimentation committee of the County of Bern under the protocol number BE119/11 and 125/14.

\section{AUTHOR CONTRIBUTIONS}

$\mathrm{CM}$ and JB designed the study. JB performed most of the experiments while CKC, DZ, NH-D, and NC contributed to the experimental work, and together with $\mathrm{JB}, \mathrm{MN}$, and $\mathrm{CM}$ analyzed and discussed the experimental data and provided conceptual advice. VG performed the histopathology scoring of intestinal tissue sections. CM supervised the work and together with JB, NC, MN, and $\mathrm{CC}$ wrote the manuscript. All authors were involved in the critical editing of the manuscript.

\section{ACKNOWLEDGMENTS}

We thank all the members of the Mueller laboratory for discussions and are grateful for the technical advice and support obtained from the Center for Flow Cytometry and Cell Sorting Resources of the Department of Biomedical Research, University of Bern. We would like to thank Pfizer for kindly providing the anti-IL17F neutralizing antibody.

\section{FUNDING}

This work was supported by the Swiss National Science Foundation SNSF grant no. 31-138392 and 170084 to CM. 


\section{REFERENCES}

1. de Souza HSP, Fiocchi C. Immunopathogenesis of IBD: current state of the art. Nat Rev Gastroenterol Hepatol (2016) 13:13-27. doi:10.1038/nrgastro.2015.186

2. Strober W, Fuss IJ. Proinflammatory cytokines in the pathogenesis of inflammatory bowel diseases. Gastroenterology (2011) 140:1756-67. doi:10.1053/j. gastro.2011.02.016

3. Powrie F, Leach MW, Mauze S, Menon S, Caddle LB, Coffman RL. Inhibition of Th1 responses prevents inflammatory bowel disease in SCID mice reconstituted with CD45RBhi CD4+ T cells. Immunity (1994) 1:553-62. doi:10.1016/1074-7613(94)90045-0

4. Ito R, Shin-Ya M, Kishida T, Urano A, Takada R, Sakagami J, et al. Interferon-gamma is causatively involved in experimental inflammatory bowel disease in mice. Clin Exp Immunol (2006) 146:330-8. doi:10.1111/j.1365-2249.2006.03214.x

5. Fuchs A, Vermi W, Lee JS, Lonardi S, Gilfillan S, Newberry RD, et al. Intraepithelial type 1 innate lymphoid cells are a unique subset of IL-12and IL-15-responsive IFN- $\gamma$-producing cells. Immunity (2013) 38:769-81. doi:10.1016/j.immuni.2013.02.010

6. Hue S, Ahern P, Buonocore S, Kullberg MC, Cua DJ, McKenzie BS, et al. Interleukin-23 drives innate and T cell-mediated intestinal inflammation. J Exp Med (2006) 203:2473-83. doi:10.1084/jem.20061099

7. Muzaki AR, Tetlak P, Sheng J, Loh SC, Setiagani YA, Poidinger M, et al. Intestinal CD103(+)CD11b(-) dendritic cells restrain colitis via IFN- $\gamma-$ induced anti-inflammatory response in epithelial cells. Mucosal Immunol (2016) 9:336-51. doi:10.1038/mi.2015.64

8. Reinisch W, de Villiers W, Bene L, Simon L, Rácz I, Katz S, et al. Fontolizumab in moderate to severe Crohn's disease: a phase 2, randomized, double-blind, placebo-controlled, multiple-dose study. Inflamm Bowel Dis (2010) 16:233-42. doi:10.1002/ibd.21038

9. Kobayashi T, Okamoto S, Hisamatsu T, Kamada N, Chinen H, Saito R, et al. IL23 differentially regulates the Th1/Th17 balance in ulcerative colitis and Crohn's disease. Gut (2008) 57:1682-9. doi:10.1136/gut.2007.135053

10. Geddes K, Rubino SJ, Magalhaes JG, Streutker C, Le Bourhis L, Cho JH, et al. Identification of an innate $\mathrm{T}$ helper type 17 response to intestinal bacterial pathogens. Nat Med (2011) 17:837-44. doi:10.1038/nm.2391

11. Rovedatti L, Kudo T, Biancheri P, Sarra M, Knowles CH, Rampton DS, et al. Differential regulation of interleukin 17 and interferon gamma production in inflammatory bowel disease. Gut (2009) 58:1629-36. doi:10.1136/ gut.2009.182170

12. Eken A, Singh AK, Treuting PM, Oukka M. IL-23R+ innate lymphoid cells induce colitis via interleukin-22-dependent mechanism. Mucosal Immunol (2014) 7:143-54. doi:10.1038/mi.2013.33

13. Ivanov II, McKenzie BS, Zhou L, Tadokoro CE, Lepelley A, Lafaille JJ, et al. The orphan nuclear receptor RORgammat directs the differentiation program of proinflammatory IL-17+ T helper cells. Cell (2006) 126:1121-33. doi:10.1016/j.cell.2006.07.035

14. Leppkes M, Becker C, Ivanov II, Hirth S, Wirtz S, Neufert C, et al. RORgammaexpressing Th17 cells induce murine chronic intestinal inflammation via redundant effects of IL-17A and IL-17F. Gastroenterology (2009) 136:257-67. doi:10.1053/j.gastro.2008.10.018

15. Griseri T, Arnold IC, Pearson C, Krausgruber T, Schiering C, Franchini F, et al. Granulocyte macrophage colony-stimulating factor-activated eosinophils promote interleukin-23 driven chronic colitis. Immunity (2015) 43:187-99. doi:10.1016/j.immuni.2015.07.008

16. Buonocore S, Ahern PP, Uhlig HH, Ivanov II, Littman DR, Maloy KJ, et al. Innate lymphoid cells drive interleukin-23-dependent innate intestinal pathology. Nature (2010) 464:1371-5. doi:10.1038/nature08949

17. Harbour SN, Maynard CL, Zindl CL, Schoeb TR, Weaver CT. Th17 cells give rise to Th1 cells that are required for the pathogenesis of colitis. Proc Natl Acad Sci U S A (2015) 112:7061-6. doi:10.1073/pnas.1415675112

18. Rooks MG, Veiga P, Wardwell-Scott LH, Tickle T, Segata N, Michaud M, et al. Gut microbiome composition and function in experimental colitis during active disease and treatment-induced remission. ISME J (2014) 8:1403-17. doi:10.1038/ismej.2014.3

19. Brasseit J, Althaus-Steiner E, Faderl M, Dickgreber N, Saurer L, Genitsch V, et al. CD4 $\mathrm{T}$ cells are required for both development and maintenance of disease in a new mouse model of reversible colitis. Mucosal Immunol (2016) 9:689-701. doi:10.1038/mi.2015.93
20. Vonarbourg C, Mortha A, Bui VL, Hernandez PP, Kiss EA, Hoyler T, et al. Regulated expression of nuclear receptor ROR $\gamma$ t confers distinct functional fates to NK cell receptor-expressing $\mathrm{ROR} \gamma \mathrm{t}(+)$ innate lymphocytes. Immunity (2010) 33:736-51. doi:10.1016/j.immuni.2010.10.017

21. Harrington LE, Hatton RD, Mangan PR, Turner H, Murphy TL, Murphy KM, et al. Interleukin 17-producing CD4+ effector T cells develop via a lineage distinct from the T helper type 1 and 2 lineages. Nat Immunol (2005) 6:1123-32. doi:10.1038/ni1254

22. Fuss IJ, Neurath M, Boirivant M, Klein JS, la Motte de C, Strong SA, et al. Disparate CD4+ lamina propria (LP) lymphokine secretion profiles in inflammatory bowel disease. Crohn's disease LP cells manifest increased secretion of IFN-gamma, whereas ulcerative colitis LP cells manifest increased secretion of IL-5. J Immunol (1996) 157:1261-70.

23. Neurath MF, Weigmann B, Finotto S, Glickman J, Nieuwenhuis E, Iijima $\mathrm{H}$, et al. The transcription factor T-bet regulates mucosal $\mathrm{T}$ cell activation in experimental colitis and Crohn's disease. J Exp Med (2002) 195:1129-43. doi:10.1084/jem.20011956

24. Simpson SJ, Shah S, Comiskey M, de Jong YP, Wang B, Mizoguchi E, et al. $\mathrm{T}$ cell-mediated pathology in two models of experimental colitis depends predominantly on the interleukin 12/signal transducer and activator of transcription (Stat)-4 pathway, but is not conditional on interferon gamma expression by T cells. J Exp Med (1998) 187:1225-34. doi:10.1084/jem.187. 8.1225

25. Wedebye Schmidt EG, Larsen HL, Kristensen NN, Poulsen SS, Lynge Pedersen $\mathrm{AM}$, Claesson MH, et al. TH17 cell induction and effects of IL-17A and IL-17F blockade in experimental colitis. Inflamm Bowel Dis (2013) 19:1567-76. doi:10.1097/MIB.0b013e318286fa1c

26. Krausgruber T, Schiering C, Adelmann K, Harrison OJ, Chomka A, Pearson C, et al. T-bet is a key modulator of IL-23-driven pathogenic CD4(+) T cell responses in the intestine. Nat Commun (2016) 7:11627. doi:10.1038/ ncomms 11627

27. O'Connor W, Kamanaka M, Booth CJ, Town T, Nakae S, Iwakura Y, et al. A protective function for interleukin 17A in T cell-mediated intestinal inflammation. Nat Immunol (2009) 10:603-9. doi:10.1038/ni.1736

28. Zimmermann J, Kühl AA, Weber M, Grün JR, Löffler J, Haftmann C, et al. T-bet expression by Th cells promotes type 1 inflammation but is dispensable for colitis. Mucosal Immunol (2016) 9:1487-99. doi:10.1038/mi.2016.5

29. Lee JS, Tato CM, Joyce-Shaikh B, Gulen MF, Gulan F, Cayatte C, et al. Interleukin-23-independent IL-17 production regulates intestinal epithelial permeability. Immunity (2015) 43:727-38. doi:10.1016/j.immuni.2015.09.003

30. Maxwell JR, Zhang Y, Brown WA, Smith CL, Byrne FR, Fiorino M, et al. Differential roles for interleukin-23 and interleukin-17 in intestinal immunoregulation. Immunity (2015) 43:739-50. doi:10.1016/j.immuni.2015.08.019

31. Hueber W, Sands BE, Lewitzky S, Vandemeulebroecke M, Reinisch W, Higgins PDR, et al. Secukinumab, a human anti-IL-17A monoclonal antibody, for moderate to severe Crohn's disease: unexpected results of a randomised, double-blind placebo-controlled trial. Gut (2012) 61:1693-700. doi:10.1136/ gutjnl-2011-301668

32. Targan SR, Feagan B, Vermeire S, Panaccione R, Melmed GY, Landers C, et al. A randomized, double-blind, placebo-controlled phase 2 study of Brodalumab in patients with moderate-to-severe Crohn's disease. Am J Gastroenterol (2016) 111:1599-607. doi:10.1038/ajg.2016.298

33. Sandborn WJ, Feagan BG, Fedorak RN, Scherl E, Fleisher MR, Katz S, et al. A randomized trial of Ustekinumab, a human interleukin-12/23 monoclonal antibody, in patients with moderate-to-severe Crohn's disease. Gastroenterology (2008) 135:1130-41. doi:10.1053/j.gastro.2008.07.014

34. Herrlinger KR, Diculescu M, Fellermann K, Hartmann H, Howaldt S, Nikolov R, et al. Efficacy, safety and tolerability of vidofludimus in patients with inflammatory bowel disease: the ENTRANCE study. J Crohns Colitis (2013) 7:636-43. doi:10.1016/j.crohns.2012.09.016

35. Luger D, Silver PB, Tang J, Cua D, Chen Z, Iwakura Y, et al. Either a Th17 or a Th1 effector response can drive autoimmunity: conditions of disease induction affect dominant effector category. J Exp Med (2008) 205:799-810. doi:10.1084/jem.20071258

36. Yeh W-I, McWilliams IL, Harrington LE. IFN $\gamma$ inhibits Th17 differentiation and function via Tbet-dependent and Tbet-independent mechanisms. J Neuroimmunol (2014) 267:20-7. doi:10.1016/j.jneuroim.2013.12.001

37. Kelchtermans H, Schurgers E, Geboes L, Mitera T, Van Damme J, Van Snick J, et al. Effector mechanisms of interleukin-17 in collagen-induced arthritis in 
the absence of interferon-gamma and counteraction by interferon-gamma. Arthritis Res Ther (2009) 11:R122. doi:10.1186/ar2787

38. Shen W, Hixon JA, McLean MH, Li WQ, Durum SK. IL-22-expressing murine lymphocytes display plasticity and pathogenicity in reporter mice. Front Immunol (2015) 6:662. doi:10.3389/fimmu.2015.00662

39. Uhlig HH, McKenzie BS, Hue S, Thompson C, Joyce-Shaikh B, Stepankova R, et al. Differential activity of IL-12 and IL-23 in mucosal and systemic innate immune pathology. Immunity (2006) 25:309-18. doi:10.1016/j. immuni.2006.05.017

40. Bando JK, Colonna M. Innate lymphoid cell function in the context of adaptive immunity. Nat Immunol (2016) 17:783-9. doi:10.1038/ni.3484

41. Rankin LC, Girard-Madoux MJH, Seillet C, Mielke LA, Kerdiles Y, Fenis A, et al. Complementarity and redundancy of IL-22-producing innate lymphoid cells. Nat Immunol (2016) 17:179-86. doi:10.1038/ni.3332

42. Kwong Chung CK, Brasseit J, Althaus-Steiner E, Rihs S, Mueller C. Mouse model of reversible intestinal inflammation. Bio-protocol (2017) 7:1-11. doi:10.21769/BioProtoc. 2173
43. Corazza N, Eichenberger S, Eugster HP, Mueller C. Nonlymphocyte-derived tumor necrosis factor is required for induction of colitis in recombination activating gene (RAG)2(-/-) mice upon transfer of CD4(+)CD45RB(hi) T cells. J Exp Med (1999) 190:1479-92. doi:10.1084/jem.190.10.1479

Conflict of Interest Statement: The authors declare that the research was conducted in the absence of any commercial or financial relationships that could be construed as a potential conflict of interest.

Copyright (C) 2018 Brasseit, Kwong Chung, Noti, Zysset, Hoheisel-Dickgreber Genitsch, Corazza and Mueller. This is an open-access article distributed under the terms of the Creative Commons Attribution License (CC BY). The use, distribution or reproduction in other forums is permitted, provided the original author(s) or licensor are credited and that the original publication in this journal is cited, in accordance with accepted academic practice. No use, distribution or reproduction is permitted which does not comply with these terms. 